\title{
Expenditure trends of orphan drugs in Serbia: 8-year analysis of orphan drug market in Serbia
}

\author{
Ana V. Pejčić ${ }^{1}$, Georgi G. Iskrov ${ }^{2,3}$ \\ ${ }^{1}$ Faculty of Medical Sciences, University of Kragujevac, Kragujevac, Serbia \\ ${ }^{2}$ Department of Social Medicine and Public Health, Faculty of Public Health, Medical \\ University of Plovdiv, Plovdiv, Bulgaria \\ ${ }^{3}$ Institute for rare diseases, Plovdiv, Bulgaria
}

\section{SUMMARY}

Background/Objective: Orphan drugs are medicinal products which treat life-threatening or chronically debilitating diseases which affect small patient populations. So far there is a substantial knowledge gap on actual expenditure on orphan drugs in Serbia. Therefore, the aim of this study was to provide insight into the expenditure trends of orphan drugs in Serbia.

Material and methods: Annual reports on turnover and the consumption of pharmaceuticals in Serbia published by Medicines and Medical Devices Agency of Serbia (ALIMS) for the period 2006-2013 were used to extract data on expenditure on orphan drugs. Drugs were eligible for inclusion in the analysis if they had active European orphan designation and European marketing authorization during the period covered by the study (2006-2013). Data were analysed across time series. Simple descriptive analysis and observation of chronological trends were applied.

Results: Data for annual expenditure on 12 different orphan drugs were available in the analysed reports. Orphan drug expenditure and share of orphan drug expenditure in total drug expenditure increased constantly from 2006 to 2010. Both began to slightly decrease over the next two years (2011-2012), and then suddenly declined nearly threefold in 2013. Share of orphan drug expenditure didn't exceed $1 \%$ of total drug expenditure over a period of eight years. The highest share of expenditure on orphan drugs was attributed to imatinib (87.36\%-97.13\%), so abrupt decline in 2013 could be explained by its withdrawal from European Community Register of Orphan Medicinal Products in 2012.

Conclusions: Expenditure on orphan drugs in Serbia from 2006 to 2013 was considerably low compared to total expenditure on drugs. In the last available year we noted substantial decline of orphan drug expenditure, mainly because of imatinib losing its orphan designation. A broader time horizon would be needed to investigate long term trends.

Keywords: orphan drug, pharmaceutical expenditure, Serbia, rare disease, dispensing, consumption

Faculty of Medical Sciences, University of Kragujevac Svetozara Markovića 69, 34000 Kragujevac, Serbia

E-mail: anapejcic201502@yahoo.com 


\section{INTRODUCTION}

Rare diseases also referred to as orphan diseases, are life-threatening or severely debilitating conditions with a low prevalence and a high level of complexity [1]. It is estimated that between 5,000 and 8,000 distinct rare diseases exist today, affecting between $6 \%$ and $8 \%$ of the population in the course of their lives [1]. In other words, although rare diseases are characterized by low prevalence for each of them, the total number of people affected by rare diseases in the European Union (EU) is between 27 and 36 million [1]. Because of their specificity and the high total number of people affected, rare diseases call for a global approach based on special and combined efforts to prevent significant morbidity or avoidable premature mortality, and to improve the quality of life and socioeconomic potential of affected persons [1].

Governments of developed countries introduced the term "orphan drugs" in order to stimulate the pharmaceutical industry to develop and market medicinal products for the treatment of patients suffering from rare conditions living in their own countries [2,3]. Peculiar challenge in this area lies in the fact that societies have to provide economically sustainable model for pharmaceutical development where research and development costs will be compensated by return on investment guaranteed by the national governments or transnational funding instruments [4]. Surprisingly, unlike in recent economic history, emerging low and middle income nations are grabbing ever larger share of global pharmaceutical spending [5].

Orphan drug legislation was first introduced in the United States in 1983 in the form of The Orphan Drug Act [2, 6-7]. Singapore introduced orphan drug legislation in 1991, Japan in 1993, Australia in 1998, the EU and Taiwan in 2000, and South Korea in 2003 [2, 6, 8-9]. Authorities in Canada had announced the development of a framework for orphan drug legislation in 2012 [10]. Incentives provided to companies by orphan drug legislation include tax credits, fee reductions, assistance in formulating drug-development protocols (including scientific and technical support), accelerated marketing approval and market exclusivity up to 10 years if the drug is licensed $[2,8,11]$.

A medicinal product intended for use in the treatment of rare disease becomes an orphan drug when it is designated as an orphan medicinal product or orphan drug by the appropriate regulatory authority [2]. For instance, Committee for Orphan Medicinal Products (COMP) at the European Medicines Agency (EMA) is the regulatory authority in charge of granting orphan designations in the EU [2]. Still, granting a medicinal product orphan designation does not necessarily mean that it will also be granted marketing authorization [12]. Orphan designations are usually given based upon severity of the condition and unmet need (no therapeutic alternative or the new product provides significant clinical benefit), although criteria for designation vary somewhat among different jurisdictions $[13,14]$. In the EU an orphan medicinal product designation can be obtained if a drug is intended for the diagnosis, prevention or treatment of a life-threatening or chronically debilitating condition affecting not more than five in 10 thousand persons in the EU, or for which without incentives it is unlikely that the marketing of the medicinal product in the EU would generate sufficient return to justify the necessary investment [11]. Additional requirement is that no satisfactory method of diagnosis, prevention or treatment of the condition exists, or if it does exist, that the new product will be of significant benefit to those affected by that condition [11]. Orphan designation implies a 10-year period of market exclusivity, at the end of which the product is withdrawn from the Community Register of Orphan Medicinal Products [11].The product could be removed earlier upon request of the marketing authorization holder [11].

The purpose of orphan drug legislation is to address the unmet health needs of rare disease patients, by providing innovative therapeutic options. Stimulating orphan drug research and development was a fundamental tool. Nevertheless, it is argued that current formulations of requirement for orphan designation can be misused to artificially create orphan diseases [15]. This can happen if drugs are intended for a specific type of patient/disease (so called "targeting") or when a disease is split into separate categories, each of which shows distinctive characteristics (so called "sub-setting") $[15,16]$. This risk is especially evident in the oncology drugs field $[15,16]$. The majority of orphan drugs are indeed oncology-indicated [17].

The market for orphan drugs is dis- 
tinguishable because of specially designed regulation [18]. Orphan drugs are highly expensive due to market exclusivity, lack of alternative therapy and small market size $[16,18$, 19]. Legislation in essence creates small virtual monopolies for each orphan drug $[15,20]$. Investment in orphan drug development and marketing has become more favourable [21]. Although orphan drugs target much smaller number of patients than non-orphan drugs, the high cost of therapy and government incentives, smaller and shorter clinical trials and extended exclusivity have made them as equally viable [21]. When comparing prices of drugs intended for rare diseases, Picavet et al. found that orphan drug designation status is associated with higher prices [22].

Studies conducted in various countries reported that share of orphan drug expenditure had increased since introduction of orphan drug legislation [10,18,23-28]. However, this share represented mainly low percentage (less than $8 \%$ ) of overall drug expenditure [10,18,23-28]. Picavet et al. observed that principal determinants in the market uptake of orphan drugs across 23 countries in Europe were the gross domestic product and the availability of a formal technology assessment organization [29]. Oncology orphan drugs are associated with highest percentage of expenditures on orphan drugs [10,18,24,26,28]. In Czech Republic oncology orphan drugs generated up to $72.6 \%$ of the overall orphan drugs expenditures in 2013 [26]. In Latvia oncology drugs represented $52.99 \%$ of the total orphan drug expenditures [18]. These uneven shares point out to the different pace and nature of pharmaceutical spending evolution among the old EU-15 compared to Eastern European nations [30]. A US study found that 74 (27.8\%) orphan drugs with an orphan cancer indication had expenditures representing $26.7 \%$ (in 2007) and $34.8 \%$ (in 2013) of total orphan drug expenditures [28].

Serbia still does not have its own orphan drug legislation $[14,31]$. There is no separate orphan drug marketing authorization process, although this procedure is simplified if the drug has been authorized through the centralized procedure in the EU which is the case with the orphan drugs $[14,31,32]$. Orphan drugs are also exempted of the fees that are generally applicable to other drugs during the process of marketing authorization [32]. Special policy regulates import of medicines and medical devices without marketing authorization including drugs intended for treatment of rare diseases [33]. There is a list of 255 rare diseases for which Medicines and Medical Devices Agency of Serbia (ALIMS) can authorize import of drugs without marketing authorization [33]. There is also a legal procedure for import of an unregistered drug as a donation or humanitarian aid [33]. Since Serbia is not a member of the EU, the country is not represented at EMA and COMP [31, 34]. However, the National Organisation for Rare Diseases of Serbia (NORBS) is a part of the European Organisation for Rare Diseases (EURORDIS) that has its delegates in the COMP $[34,35]$.

The National Health Insurance Fund of Serbia is a national, public and non-profit organization which is financed by payment of health insurance contributions [36, 37]. In this way, citizens finance their healthcare by mediation of the Serbian Health Insurance Fund $[36,38]$. One recently published study have shown that in 2011 only 4 orphan drugs were included in the reimbursement list, representing $6.5 \%$ of the market available orphan drugs in the EU [39]. Two years later, in 2013, only 9 of those medicinal products were registered in Serbia with only two (cladribine and imatinib) being actually reimbursed [40]. In order to be accessible to Serbian rare disease patients, an orphan drug has to be included in the Reimbursement list. A drug requires marketing authorization, as well as pharmacoeconomic evaluation to be included in Reimbursement List A, A1, B or C [41]. One exemption to this rule is a possibility to include an unregistered drug in the Reimbursement List D, if the drug is necessary in the treatment and diagnostics [42]. However, high price of orphan drugs is a considerable limiting factor for their inclusion in this list. If the National Health Insurance Fund cannot reimburse the expenditures related to the health care of patients affected by rare diseases, the Government of Serbia may allocate funding on an annual base [43]. The Government through the Ministry of Health allocated RSD 130 million (around EUR 1.2 million) in 2013, with RSD 280 million (around EUR 2.6 million) planned for this purpose in 2014 [31]. This amount was intended for treatments for only a handful of paediatric patients with metabolic diseases requiring enzyme replacement therapies [31]. In 2015 the Ministry of Health allocated RSD 335.2 million (around EUR 2.8 million) [44] and in 2016 it almost 
doubled the amount RSD 600 million (around EUR4.9 million) [45] intended for health care of patients with rare diseases. However, all of this is still not enough to cover the healthcare expenditure of estimated 500,000 of patients with various rare diseases in Serbia [39]. A proposal for a national Strategy on Rare Diseases was developed in 2013 envisioning a number of actions, including improving diagnostics and availability of orphan drugs [31]. Even so, the Strategy has not been officially adopted yet and there is still no national registry for rare diseases, although there are national registries for individual rare diseases (cystic fibrosis, haemophilia and rare coagulopathies) [31].

Total public expenditure on pharmaceuticals in Serbia constantly increased from 2004 to $2012[46,47]$. At the same time not all segments of pharmaceutical market had shown the same trend [46-48]. Market growth was primarily driven by cardiovascular medicines, targeted oncology agents and a variety of advanced biologicals [46]. So far there is a substantial knowledge gap on actual expenditure on orphan drugs in Serbia. Therefore, the aim of this study was to provide insight into the expenditure trends of orphan drugs in Serbia.

\section{MATERIAL AND METHODS}

Annual reports on turnover and consumption of pharmaceuticals in Serbia published by ALIMS were used as main data source. These reports are publicly available on ALIMS website for the period 2006-2013 [49-56]. They are based on information about amount of imported pharmaceuticals and their market placement provided by manufacturers and their legal representatives in Serbia. Data in these reports are ordered by Anatomical Therapeutic Chemical (ATC) classification codes. Each ATC code group and each single product are assigned financial value of its sales in national currency, Serbian Dinar (RSD).

Currently, there is no official list of orphan designated medicinal products in Serbia. Therefore, this analysis used information on market authorized orphan drugs in the EU from Orphanet, expert-authored and peerreviewed database of rare diseases [57]. Drugs were eligible for inclusion in the analysis if they had active European orphan designation and European marketing authorization during the period covered by the study (2006-2013).
We included drugs in the analysis until the end of the year in which they were formally considered orphan medicinal products in Europe. Information on ATC code and pharmaceutical form of each authorized drug was obtained from the Summary of product characteristics from the EMA website [58]. The same website was used to check exact dates of inclusion and/ or withdrawal of the drug from the European Community Register of designated Orphan Medicinal Products. These data were then cross-referenced with data on expenditure in the annual reports of ALIMS.Annual expenditure for each orphan drug was extracted considering ATC, INN and marketed pharmaceutical form. Information on total annual expenditure on pharmaceuticals in Serbia was also extracted. Average middle exchange rate for Euro (EUR) given by the National Bank of Serbia for each observed year was used to convert expenditures originally reported in the national currency (RSD) [59]. Average annual middle exchange rates for EUR 1 were as follows: 84.1560 in 2006, 79.9775 in 2007, 81.4381 in 2008, 93.8992 in 2009, 102.8993 in 2010, 101.9653 in 2011, 113.0415 in 2012 and 113.0924 in 2013.

Data were analysed across time series. Simple descriptive analysis and observation of chronological trends were applied. Total orphan drug expenditures were calculated annually from 2006 to 2013 and further reported as a percentage of total annual drug expenditures (share of orphan drug expenditure in total drug expenditure). Annual expenditure increment for a specific orphan drug was calculated by dividing total change of available expenditures with reported time span (for drugs with data available for at least two different years). Charts were developed in Microsoft Office Excel $2007^{\circ}$.

\section{RESULTS}

Data for annual expenditure on 12 different orphan drugs were available in ALIMS reports during the period covered by the study (Table 1a and Table 1b). Most of them (8 drugs, i.e. 66.67\%) belonged to ATC category L (Antineoplastic and immunomodulating agents), two $(16.67 \%)$ to category A (Alimentary tract and metabolism), one (8.33\%) to category B (Blood and the blood forming organs) and one $(8.33 \%)$ to category C (Cardiovascular system). 
Table 1a. Expenditure on orphan drugs in Serbia from 2006 to 2013.

*Source of data: Medicines and Medical Devices Agency of Serbia- ALIMS. Blanks indicate that there was no expenditure in the report for an orphan drug in a given year.

ATC - Anatomical Therapeutic Chemical Classification code INN - international nonproprietary name;

RSD - Serbian Dinar;
EUR - Euro

\begin{tabular}{|c|c|c|c|c|c|c|}
\hline ATC & INN & & 2006 & 2007 & 2008 & 2009 \\
\hline \multirow{2}{*}{ A16AB04 } & \multirow{2}{*}{$\begin{array}{l}\text { agalsidase } \\
\text { beta }\end{array}$} & RSD & & & & $15,716,972.8$ \\
\hline & & EUR & & & & $167,381.3$ \\
\hline \multirow{2}{*}{ A16AB05 } & \multirow{2}{*}{ laronidase } & RSD & & & & \\
\hline & & EUR & & & & \\
\hline \multirow{2}{*}{ В02BX04 } & \multirow{2}{*}{ romiplostim } & RSD & & & & \\
\hline & & EUR & & & & \\
\hline \multirow{2}{*}{ C02KX01 } & \multirow{2}{*}{ bosentan } & RSD & & & & \\
\hline & & EUR & & & & \\
\hline \multirow{2}{*}{ L01AB01 } & \multirow{2}{*}{ busulfan } & RSD & $1,237,595.5$ & & $5,445,440.0$ & $3,465,280.0$ \\
\hline & & EUR & $14,706.0$ & & $66,866.0$ & $36,904.3$ \\
\hline \multirow{2}{*}{ L01BB04 } & \multirow{2}{*}{ cladribine } & RSD & $4,768,453.2$ & $3,746,641.8$ & $8,004,189.3$ & $9,593,660.0$ \\
\hline & & EUR & $56,662.1$ & $46,846.2$ & $98,285.6$ & $102,169.8$ \\
\hline \multirow{2}{*}{ L01XE01 } & \multirow{2}{*}{ imatinib } & RSD & $121,458,060.0$ & $180,972,509.4$ & $334,349,704.5$ & $396,170,313.0$ \\
\hline & & EUR & $1,443,249.0$ & $2,262,792.8$ & $4,105,568.6$ & $4,219,102.1$ \\
\hline \multirow{2}{*}{ L01XE05 } & \multirow{2}{*}{ sorafenib } & RSD & & & $14,961,954.0$ & $2,932,039.2$ \\
\hline & & EUR & & & $183,721.8$ & $31,225.4$ \\
\hline \multirow{2}{*}{ L01XE06 } & \multirow{2}{*}{ dasatinib } & RSD & & $1,600,000.0$ & & \\
\hline & & EUR & & $20,005.6$ & & \\
\hline \multirow{2}{*}{ L01XE08 } & \multirow{2}{*}{ nilotinib } & RSD & & & & \\
\hline & & EUR & & & & \\
\hline \multirow{2}{*}{ L01XE09 } & \multirow{2}{*}{ temsirolimus } & RSD & & & & $18,592,284.6$ \\
\hline & & EUR & & & & $198,002.6$ \\
\hline \multirow{2}{*}{ L01XE10 } & \multirow{2}{*}{ everolimus } & RSD & & & & \\
\hline & & EUR & & & & \\
\hline \multirow{2}{*}{\multicolumn{2}{|c|}{$\begin{array}{l}\text { Orphan drug expendi- } \\
\text { ture }\end{array}$}} & RSD & $127,464,108.7$ & $186,319,151.2$ & $362,761,287.8$ & $446,470,549.6$ \\
\hline & & EUR & $1,514,617.0$ & $2,329,644.6$ & $4,454,441.9$ & $4,754,785.4$ \\
\hline \multirow{2}{*}{\multicolumn{2}{|c|}{$\begin{array}{l}\text { Orphan drug expendi- } \\
\text { ture (imatinib excluded) }\end{array}$}} & RSD & $6,006,048.7$ & $5,346,641.8$ & $28,411,583.3$ & $50,300,236.6$ \\
\hline & & EUR & $71,368.0$ & $66,851.8$ & $348,873.4$ & $535,683.3$ \\
\hline \multirow{2}{*}{\multicolumn{2}{|c|}{$\begin{array}{l}\text { Total public drug expen- } \\
\text { diture in Serbia }\end{array}$}} & RSD & $42,389,483,753.4$ & $55,237,826,083.7$ & $65,972,228,169.7$ & $71,200,588,899.8$ \\
\hline & & EUR & $503,701,266.1$ & $690,667,076.2$ & $810,090,463.4$ & $758,266,192.9$ \\
\hline
\end{tabular}

Figure 1. Orphan drug expenditure trend 2006-2013
The lowest orphan drug expenditure was observed in 2006 (around RSD 127 million, i.e. EUR 1.5 million), whereas the highest was observed in 2010 (around RSD 754 million, i.e. EUR 7.3 million) (Table 1a and Table 1b). Orphan drug expenditure increased constantly from 2006 to 2010 . It began to slightly decrease over the next two years (2011-2012),

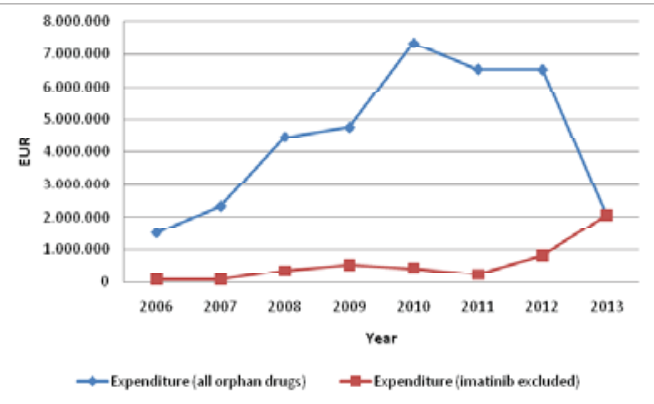

and then it suddenly declined nearly threefold in 2013 (Blue line on Figure 1). Similar trend was observed for the share of orphan drug expenditure in total drug expenditure (Blue line on Figure 2). Maximum percentage of orphan drug expenditure in the total drug expenditure was $1.0 \%$ in 2010 , but minimum of $0.26 \%$ was reached in 2013.

The highest annual expenditure increment of orphan drugs was attributed to imatinib (Table 2). Over the time span of 6 years, i.e. from 2006 to 2012, expenditure on imatinib increased approximately RSD 87 million (EUR 708 thousand) per year. Share of expenditure on imatinib in total orphan drug expenditure varied from $87.36 \%$ to $97.13 \%$ (Figure 3). In 2012 imatinib was withdrawn from the European Community Register of 


\begin{tabular}{|c|c|c|c|c|c|c|}
\hline ATC & INN & & 2010 & 2011 & 2012 & 2013 \\
\hline \multirow{2}{*}{ A16AB04 } & \multirow{2}{*}{$\begin{array}{l}\text { agalsidase } \\
\text { beta }\end{array}$} & RSD & & & & \\
\hline & & EUR & & & & \\
\hline \multirow{2}{*}{ A16AB05 } & \multirow{2}{*}{ laronidase } & RSD & & & $3,284,685.0$ & $38,837,899.1$ \\
\hline & & EUR & & & $29,057.3$ & $343,417.4$ \\
\hline \multirow{2}{*}{ В02BX04 } & \multirow{2}{*}{ romiplostim } & RSD & & & & $3,647,244.0$ \\
\hline & & EUR & & & & $32,250.1$ \\
\hline \multirow{2}{*}{ C02KX01 } & \multirow{2}{*}{ bosentan } & RSD & & & & $10,513,589.0$ \\
\hline & & EUR & & & & $92,964.6$ \\
\hline \multirow{2}{*}{ L01AB01 } & \multirow{2}{*}{ busulfan } & RSD & & $990,080.0$ & & \\
\hline & & EUR & & $9,710.0$ & & \\
\hline \multirow{2}{*}{ L01BB04 } & \multirow{2}{*}{ cladribine } & RSD & $4,080,250.7$ & $4,476,150.0$ & $3,037,378.0$ & $4,695,849.6$ \\
\hline & & EUR & $39,652.9$ & $43,898.8$ & $26,869.6$ & $41,522.2$ \\
\hline \multirow{2}{*}{ L01XE01 } & \multirow{2}{*}{ imatinib } & RSD & $711,430,732.8$ & $641,983,274.1$ & $643,237,292.3$ & \\
\hline & & EUR & $6,913,854.0$ & $6,296,095.6$ & $5,690,275.6$ & \\
\hline \multirow{2}{*}{ L01XE05 } & \multirow{2}{*}{ sorafenib } & RSD & $4,330,426.8$ & $2,450,001.4$ & $700,000.0$ & $3,060,232.0$ \\
\hline & & EUR & $42,084.1$ & $24,027.8$ & $6,192.4$ & $27,059.6$ \\
\hline \multirow{2}{*}{ L01XE06 } & \multirow{2}{*}{ dasatinib } & RSD & & & & \\
\hline & & EUR & & & & \\
\hline \multirow{2}{*}{ L01XE08 } & \multirow{2}{*}{ nilotinib } & RSD & $826,228.4$ & $15,788,192.0$ & $83,677,417.6$ & $171,184,358.4$ \\
\hline & & EUR & $8,029.5$ & $154,838.9$ & $740,236.3$ & $1,513,668.1$ \\
\hline \multirow{2}{*}{ L01XE09 } & \multirow{2}{*}{ temsirolimus } & RSD & $33,655,615.0$ & & & \\
\hline & & EUR & $327,073.3$ & & & \\
\hline \multirow{2}{*}{ L01XE10 } & \multirow{2}{*}{ everolimus } & RSD & & & $2,395,328.8$ & $2,621,241.7$ \\
\hline & & EUR & & & $21,189.8$ & $23,177.9$ \\
\hline \multirow{2}{*}{\multicolumn{2}{|c|}{$\begin{array}{l}\text { Orphan drug expendi- } \\
\text { ture }\end{array}$}} & RSD & $754,323,253.7$ & $665,687,697.5$ & $736,332,101.7$ & $234,560,413.8$ \\
\hline & & EUR & $7,330,693.7$ & $6,528,571.0$ & $6,513,821.1$ & $2,074,059.9$ \\
\hline \multirow{2}{*}{\multicolumn{2}{|c|}{$\begin{array}{l}\text { Orphan drug expendi- } \\
\text { ture (imatinib excluded) }\end{array}$}} & RSD & $42,892,520.9$ & $23,704,423.4$ & $93,094,809.4$ & $234,560,413.8$ \\
\hline & & EUR & $416,839.8$ & $232,475.4$ & $823,545.4$ & $2,074,059.9$ \\
\hline \multirow{2}{*}{\multicolumn{2}{|c|}{$\begin{array}{l}\text { Total public drug expen- } \\
\text { diture in Serbia }\end{array}$}} & RSD & $75,397,383,619.6$ & $74,003,411,597.4$ & $84,188,905,685.4$ & $91,342,622,729.1$ \\
\hline & & EUR & $732,729,801.1$ & $725,770,547.4$ & $744,761,045.2$ & $807,681,353.7$ \\
\hline
\end{tabular}

Orphan Medicinal Products. Therefore,the observed abrupt decline in 2013 could be explained by this event. If we exclude imatinib from analysed data we can notice a totally different trend. Orphan drug expenditure without imatinib increased more than 7 -fold with occasional variations from around RSD 6 million (EUR 71 thousand) in 2006 to around RSD 93 million (EUR 824 thousand) in 2012 (Table 1a and Table 1b). Increase was most prominent in 2013 with orphan drug expenditure almost 2.5 -fold greater than the one in previous year (around RSD 235 million, i.e. EUR 2.1 million) (Red line on Figure 1). Share of orphan drug expenditure in total drug expenditure also showed a similar trend(Red line on Figure 2). It increased from $0.01 \%$ to $0.11 \%$ with slight variations from 2006 to 2012, and then in 2013

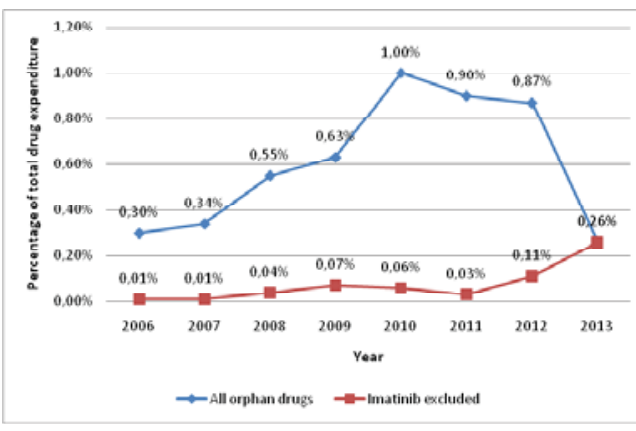

it reached maximum of $0.26 \%$.

\section{DISCUSSION}

Expenditure on orphan drugs in Serbia from 2006 to 2013 was considerably low compared to total expenditure on drugs. It didn't exceed
Table 1b. Expenditure on orphan drugs in Serbia from 2006 to 2013.

*Source of data: Medicines and Medical Devices Agency of Serbia- ALIMS. Blanks indicate that there was no expenditure in the report for an orphan drug in a given year.

ATC - Anatomical Therapeutic Chemical Classification code

INN - international nonproprietary name;

RSD - Serbian Dinar;

EUR - Euro

Figure 2. Share of orphan drug expenditure in total drug expenditure (2006-2013) 
Table 2. Total change, time span and annual expenditure increment for orphan drugs with available data for at least two different years.

ATC - Anatomical Therapeutic Chemical Classification code INN - international nonproprietary name;

RSD - Serbian Dinar;

EUR - Euro

Figure 3. Share of expenditure on imatinib in total orphan drug expenditure (2006-2012)

\begin{tabular}{|c|c|c|c|c|c|c|}
\hline & ATC & INN & & Total change & Time span & Annual increment \\
\hline \multirow{2}{*}{1.} & \multirow{2}{*}{ L01XE01 } & \multirow{2}{*}{ imatinib } & RSD & $521,779,232.3$ & 6 & $86,963,205.4$ \\
\hline & & & EUR & $4,247,026.6$ & 6 & $707,837.8$ \\
\hline \multirow{2}{*}{2.} & \multirow{2}{*}{ L01XE08 } & \multirow{2}{*}{ nilotinib } & RSD & $170,358,130.0$ & 3 & $56,786,043.3$ \\
\hline & & & EUR & $1,505,638.6$ & 3 & $501,879.5$ \\
\hline \multirow{2}{*}{3.} & \multirow{2}{*}{ A16AB05 } & \multirow{2}{*}{ laronidase } & RSD & $35,553,214.1$ & 1 & $35,553,214.1$ \\
\hline & & & EUR & $314,360.1$ & 1 & $314,360.1$ \\
\hline \multirow{2}{*}{4.} & \multirow{2}{*}{ L01XE09 } & \multirow{2}{*}{ temsirolimus } & RSD & $15,063,330.4$ & 1 & $15,063,330.4$ \\
\hline & & & EUR & $129,070.7$ & 1 & $129,070.7$ \\
\hline \multirow{2}{*}{5.} & \multirow{2}{*}{ L01XE10 } & \multirow{2}{*}{ everolimus } & RSD & $225,912.9$ & 1 & $225,912.9$ \\
\hline & & & EUR & $1,988.1$ & 1 & $1,988.1$ \\
\hline \multirow{2}{*}{6.} & \multirow{2}{*}{ L01BB04 } & \multirow{2}{*}{ cladribine } & RSD & $-72,603.6$ & 7 & $-10,371.9$ \\
\hline & & & EUR & $-15,139.8$ & 7 & $-2,162.8$ \\
\hline \multirow{2}{*}{7.} & \multirow{2}{*}{ L01AB01 } & \multirow{2}{*}{ busulfan } & RSD & $-247,515.5$ & 5 & $-49,503.1$ \\
\hline & & & EUR & $-4,996.0$ & 5 & -999.2 \\
\hline \multirow{2}{*}{8.} & \multirow{2}{*}{ L01XE05 } & \multirow{2}{*}{ sorafenib } & RSD & $-11,901,722.0$ & 5 & $-2,380,344.4$ \\
\hline & & & EUR & $-156,662.2$ & 5 & $-31,332.4$ \\
\hline
\end{tabular}

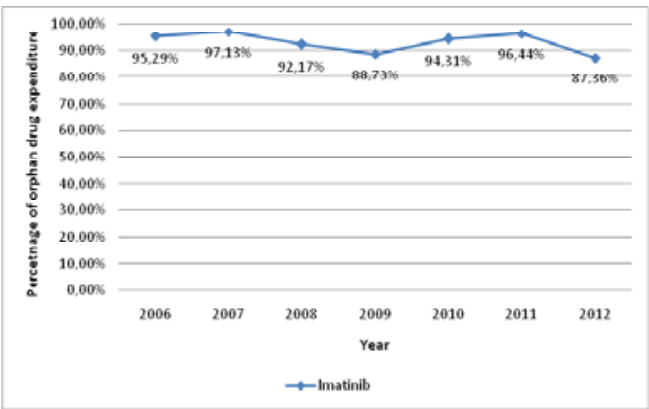

$1 \%$ of total drug expenditure over a period of eight years. This percentage is similar to that reported in 2004 in an early European study (0.7-1\% per country) [60] and in one recently published Latvian study for 2010-2014 (0.70$1.04 \%)$ [18]. However, when comparing these results, it should be kept in mind that methods and data sources vary significantly (sales data, national health care funds etc.). Access to orphan drugs depends on individual country's pricing and reimbursement policies. Subsequent studies in Europe reported slightly higher share of orphan drug expenditure in total drug expenditure. Average budget impact of orphan drugs represented $1.7 \%$ of the total expenditure on drugs in 2007 across the five countries (the United Kingdom, Germany, Italy, Spain and France) [61]. The budget impact of orphan drugs represented $2.5 \%$ of total drug expenditure in Sweden and 3.1\% in France in 2012 [62]. The share of orphan drugs in total pharmaceutical market in 2013 reached 3.6\% in Czech Republic [26] and 3.2\% in Poland [27]. The Netherlands reported highest share of
$4.2 \%$ in 2012 [23]. Countries located in North America reported even higher shares. Share of orphan drug expenditure in total pharmaceutical drug expenditure reached $5.6 \%$ in Cana$\mathrm{da}$ [10] and 7.6\% in the United States in 2013 [28]. Such high share reported in the United States is certainly not surprising, considering the fact that it was the first country which introduced orphan drug legislation.

Share of orphan drug expenditure in total drug expenditure in Serbia increased constantly from 2006 to 2010 . It began to slightly decrease over the next two years (2011-2012), and then it suddenly declined nearly threefold in 2013 due to withdrawal of imatinib from the European Community Register of Orphan Medicinal Products. Decline was striking, from $0.87 \%$ in 2012 to only $0.26 \%$ in 2013 . Similar occurrence was noted in Latvia, only the decline was not so abrupt [18]. In Latvia share of total pharmaceutical market attributed to orphan drugs decreased from $1.04 \%$ in 2012 to $0.70 \%$ in 2013 [18]. This difference could be explained by the fact that imatinib constituted from $87.36 \%$ to $97.13 \%$ of all orphan drug expenditures in Serbia, whereas in Latvia it was about $34 \%$ [18]. When change in share of orphan drug expenditure was analysed without imatinib, more-less constant increase was observed from 2006 to 2013 in Serbia. Similar trend was reported for Latvia [18]. ALIMS has not yet made publicly available the annual report on turnover and consumption of drugs for 2014 on its website [63], so we do not know if orphan drug expenditure increased in 
the following year. In Latvia it increased to $0.84 \%$ in 2014 [18]. Orofino et al. described similar budget impact of imatinib in the study that only considered orphan drug expenditure in 2007 across the five countries (the UnitedKingdom, Germany, Italy, Spain and France) [61]. Sales of imatinib in all five countries accounted EUR 679 million, which was $41.2 \%$ of the total expenditure on the 38 orphan drugs [61]. They stipulated that if they excluded the expenditure corresponding to the three drugs that each had sales that exceeded EUR 150 million (sunitinib, bosentan and imatinib), the impact of the remaining 35 orphan drugs on the overall drug expenditure in the five countries would be more than halved, from $1.7 \%$ to $0.65 \%$ [61]. Some argue that the distribution of orphan drug sales is skewed, and that the success of some outlier orphan drugs, such as imatinib, has contributed to an impression that orphan drugs consistently achieve high sales [62].

Some other European countries reported more-less constant growth of orphan drug budget impact [62]. In Sweden it grew at a steady rate from introduction of orphan drug legislation reaching $0.7 \%$ of total drug sales in 2006 [62]. The budget impact growth rate accelerated between 2006 and 2009, and then slowed down reaching $2.5 \%$ of total pharmaceutical market value in 2012 [62]. In Czech Republic share of orphan drugs in total pharmaceutical sales grew steadily from $2.5 \%$ in 2008 , reaching $3.4 \%$ in 2011 and plateaued at $3.6 \%$ in 2013 [26].

Lower share of expenditures on orphan drugs in Serbia might be explained by the discrepancies in the marketing authorization, pricing and reimbursement of orphan drugs compared to the $\mathrm{EU}$ and other countries [34]. These are indeed very common challenges to orphan drug access in Eastern Europe [64]. Lack of epidemiological registries and low public awareness on rare diseases are also aggravating this problem [64]. Since Serbia is not an EU Member State there is no centralised marketing authorization procedure and the registration procedure can take up to one year, which leads to delay in access to orphan drugs $[31,34]$. Considering the fact that there is usually no difference in prices of orphan drugs between developed and less developed countries, it is harder for patients in less developed countries to afford such treatments [65]. Drugs for some rare disease are frequently do- nated by charity for the most severe cases until the state accepts participation in the financing of treatment [65]. However, majority of patients affected by rare diseases in Serbia stil cannot get reimbursement for their treatment from the Republic Health Insurance Fund [31, 65].

Only a minority of expenditures on orphan drugs was associated with non-oncological indications: Fabry's disease (agalsidase beta (Fabrazyme ${ }^{\circ}$ ) in 2009), mucopolysaccharidosis type I (laronidase (Aldurazyme ${ }^{\circledast}$ ) in 2012 and 2013), idiopathic thrombocytopenic purpura (romiplostim (Nplate ${ }^{\otimes}$ ) in 2013) and class III pulmonary arterial hypertension (bosentan (Tracleer ${ }^{\circ}$ ) in 2013). These findings are in line with one recently published study which concluded that expenditure on drugs with primary oncology-related indications in Serbia increased by approximately five times during the period 2004-2012 [66].

Current studies suggest that orphan drug expenditure will likely remain a small proportion of total pharmaceutical expenditure $[10,62,67]$. The impact of orphan drugs on the total European pharmaceutical market was predicted to increase from $3.3 \%$ in 2010 to $4.6 \%$ in 2016 [67]. Share of orphan drug expenditure in the total pharmaceutical market was forecasted to grow to $4.1 \%$ in Sweden and $4.9 \%$ in France by 2020 [62]. Future trend analysis in Canada suggested that orphan drug expenditure in 2014-2018 will remain stable below $6 \%$ of total drug expenditure [10]. It remains to be seen how orphan drug market will continue to evolve in Serbia.

\section{Study limitations}

In our research we focused only on drugs that were orphan designated during the period covered by our study. Not all drug therapies intended for rare diseases are orphan designated. Furthermore, current orphan drug legislation provides a possibility for a drug to be orphan designated even if it is intended to treat a subset of the patient population with a common disease. So we did not capture expenditure on all drugs intended for rare disease treatment.

ALIMS annual reports are based on information about amount of imported and priced pharmaceuticals and their market placement provided by manufacturers and their legal representatives. So, these reports give only an approximate amount of sales generated without considering specific terms of sale. 
Moreover, real drug use may differ from that reflected in the sales data. Orphan drugs are provided to some patients through donations, and therefore, the sales data do not capture this. The time period in our study was limited to a period of eight years. In the last available year we noted substantial decline of orphan drug expenditure, mainly because of imatinib losing its orphan designation. A broader time horizon would be needed to investigate long term trends.

\section{CONCLUSION}

Total spending on orphan drugs represented a small share of overall expenditure on drugs during the observed period (2006-2013). Share of orphan drug expenditure didn't exceed 1\% of total drug expenditure over a period of eight years. Orphan drug expenditure and share of orphan drug expenditure in total drug expenditure increased constantly from 2006 to 2010 . It began to slightly decrease over the next two years (2011-2012), and then it suddenly declined nearly threefold in 2013. More than $87 \%$ of expenditure on orphan drugs was attributed to imatinib, so abrupt decline in 2013 could be explained by its withdrawal from European Community Register of Orphan Medicinal Products in 2012. When imatinib was excluded from analysis, both orphan drug expenditure and share of orphan drug expenditure in total drug expenditure increased constantly with slight variations. A broader time horizon would be needed to investigate long term trends.

\section{ACKNOWLEDGEMENTS}

Ana V. Pejčić is awarded with the Scholarship of the Ministry of Education, Science and Technological Development of the Republic of Serbia for PhD students. Publication of results was not contingent to Ministry's censorship or approval.

\section{CONFLICT OF INTEREST}

The authors have no conflicts of interest that are directly relevant to the content of this manuscript.

\section{REFERENCES}

1. Council recommendation of 8 June 2009 on an action in the field of rare diseases (2009/C 151/02). Official Journal of the European Union 2009, C151:710. [cited 2016Aug 12]. Available from: http://eurlex.europa.eu/LexUriServ/LexUriServ.do?uri=OJ:C: 2009:151:0007:0010:EN:PDF.

2. Wästfelt M, Fadeel B, Henter JI. A journey of hope: lessons learned from studies on rare diseases and orphan drugs. J Intern Med. 2006;260(1):1-10.

3. Wonder M, Chin G. What impact does 'conventional' economic evaluation have on patient access to new orphan medicines? A comparative study of their reimbursement in Australia (2005. 2012). Expert Rev Pharmacoecon Outcomes Res. 2015;15(5):843-50.

4. Jakovljevic M, Ogura S. Health Economics at the Crossroads of Centuries - From the Past to the Future. Front Public Health. 2016;4:115.

5. Jakovljevic M, Getzen TE. Growth of Global Health Spending Share in Low and Middle Income Countries. Front Pharmacol. 2016;7:21.

6. Kontoghiorghe $\mathrm{CN}$, Andreou $\mathrm{N}$, Constantinou $\mathrm{K}$, Kontoghiorghes GJ. World health dilemmas: Orphan and rare diseases, orphan drugs and orphan patients. World J Methodol. 2014;4(3):163-88.

7. Cohen JP, Felix A. Are payers treating orphan drugs differently? J Mark Access Health Policy. 2014;2:23513.

8. Song P, Gao J, Inagaki Y, Kokudo N, Tang W. Rare diseases, orphan drugs, and their regulation in Asia: Current status and future perspectives. Intractable Rare Dis Res. 2012;1(1):3-9.

9. Jakovljevic MB, Nakazono S, Ogura S. Contemporary generic market in Japan - key conditions to successful evolution. Expert Rev Pharmacoecon Outcomes Res. 2014;14(2):181-94.

10. Divino V, DeKoven $M$, Kleinrock $M$, Wade RL, Kim T, Kaura S. Pharmaceutical expenditure on drugs for rare diseases in Canada: a historical (2007-13) and prospective (2014-18) MIDAS sales data analysis. Orphanet J Rare Dis. 2016;11(1):68.

11. Regulation (EC) No. 141/2000 of the European Parliament and of the Council of 16 December 1999 on Orphan Medicinal Products. Offic J Europ Communities 2000, L18:1-5.

[cited 2016 Jul 31]. Available from:http:// ec.europa.eu/health/files/eudralex/vol-1/ reg_2000_141/reg_2000_141_en.pdf.

12. Heemstra HE, de Vrueh RL, van Weely S, Büller HA, Leufkens HG. Predictors of orphan drug approval in the European Union. Eur J Clin Pharmacol. 2008;64(5):545-52.

13. Aronson JK. Rare diseases and orphan drugs. $\mathrm{Br}$ J Clin Pharmacol. 2006;61(3):243-5. 
14. Gammie T, Lu CY, Babar ZU. Access to Orphan Drugs: A Comprehensive Review of Legislations, Regulations and Policies in 35 Countries. PLoS One. 2015;10(10):e0140002.

15. Denis A, Mergaert L, Fostier C, Cleemput I, Simoens $\mathrm{S}$. Issues surrounding orphan disease and orphan drug policies in Europe. Appl Health Econ Health Policy. 2010;8(5):343-50.

16. Simoens S. Pricing and reimbursement of orphan drugs: the need for more transparency. Orphanet J Rare Dis. 2011;6:42.

17. Winstone J, Chadda S, Ralston S, Sajosi P. Review and comparison of clinical evidence submitted to support European Medicines Agency market authorization of orphan-designated oncological treatments. Orphanet J Rare Dis. 2015;10:139.

18. Logviss K, Krievins D, Purvina S. Impact of orphan drugs on Latvian budget. Orphanet J Rare Dis. 2016;11(1):59.

19. Gong S, Wang $Y$, Pan X, Zhang L, Huang R, Chen $\mathrm{X}$, Hu J, Xu Y, Jin S. The availability and affordability of orphan drugs for rare diseases in China. Orphanet J Rare Dis. 2016;11:20.

20. Denis A, Mergaert L, Fostier C, Cleemput I, Simoens $\mathrm{S}$. Budget impact analysis of orphan drugs in Belgium: estimates from 2008 to 2013. J Med Econ 2010;13(2):295-301.

21. Meekings KN, Williams CS, Arrowsmith JE. Orphan drug development: an economically viable strategy for biopharma R\&D. Drug Discov Today. 2012;17(13-14):660-4.

22. Picavet E, Dooms M, Cassiman D, Simoens $S$. Drugs for rare diseases: influence of orphan designation status on price. Appl Health Econ Health Policy. 2011;9(4):275-9.

23. Kanters TA, Steenhoek A, Hakkaart L. Orphan drugs expenditure in the Netherlands in the period 2006-2012. Orphanet J Rare Dis. 2014;9:154.

24. Kockaya G, Wertheimer Al, Kilic P, Tanyeri P, Vural iM, Akbulat A, Artiran G, Kerman S. An overview of the orphan medicines market in Turkey. Value in Health Reg Issues. 2014;4:47-52.

25. Chiang P, Yang W. PSY82 - The expenditure and reimbursement of orphan drug in Taiwan: challenges and opportunities. Value in Health 2016;19(3):A255.

26. Vocelka M, Spurna M, Fuksa L, Hambalek J. PSY27 - Public Expenditure On Authorised Orphan Drugs In the Czech Republic Between 2008 and 2013. Value in Health 2014;17(7):A526.

27. Sujkowska G, Jagodzinska-Kalinowska K, Matusewicz W. PSY72 - The availability and Expenditure of Orphan Medicines in Poland. Value in Health 2015;18(3):A304.

28. Divino V, Dekoven M, Wang W, Kleinrock M, Har- vey $\mathrm{RD}$, Wade RL, Kaura S.The Budget Impact of Orphan Drugs in the U.S.: A 2007-2013 MIDAS Sales Data Analysis. Blood 2014;124(21):736.

29. Picavet E, Annemans L, Cleemput I, Cassiman D, Simoens S. Market uptake of orphan drugs - a European analysis. J Clin Pharm Ther. 2012;37(6):664-7.

30. Jakovljevic $M$, Lazarevic $M$, Milovanovic $O$, Kanjevac T. The New and Old Europe: East-West Split in Pharmaceutical Spending. Front Pharmacol. 2016;7:18

31. Rodwell C, Aymé S (editors). 2014 Report on the State of the Art of Rare Disease Activities in Europe, July 2014. [cited 2016Aug 05]. Available from:http: //www.eucerd.eu/upload/file/Reports/ 2014ReportStateofArtRDActivitiesRS.pdf.

32. Law on Medicines and Medical Devices. The Official Gazette of the Republic of Serbia, 30/2010 and 107/2012. [cited 2016Aug 05]. Available from: http://www.alims.gov.rs/ciril/files/2012/11/zakon-30-2010-107-2012.doc.

33. Regulations of Conditions for the Import of Medicines and Medical Devices without Marketing Authorisation. The Official Gazette of the Republic of Serbia, 02/2014, 14/2014, 111/2014 and 52/2015. [cited 2016Aug 07]. Available from: http://www. rfzo.rs/download/pravilnici/mz/Pravilnik_uvoz bezregistra-19062015.pdf.

34. Pavlović N, Stanimirov B, Stojančević M, PautKusturica M, Goločorbin-Kon S, Mikov M. PSY73 - Low availability of orphan medicines in Serbia. Value in Health 2013;16(3):A123-4.

35. National Organisation for Rare Diseases of Serbia [Internet]. About National Organisation for Rare Diseases of Serbia. [cited 2016Aug 05]. Available from: http://www.norbs.rs/o-norbs-u/.

36. The National Health Insurance Fund of the Republic of Serbia [Internet]. About National Health Insurance Fund of the Republic of Serbia. [cited 2016Aug 07]. Available from: http://www.eng.rfzo. rs/index.php/aboutus.

37. Jakovljevic M, Jovanovic M, Lazic Z, Jakovljevic V, Djukic A, Velickovic R, Antunovic M. Current efforts and proposals to reduce healthcare costs in Serbia. Ser J Exp Clin Res. 2011;12(4):161-3.

38. Jakovljevic MB. Resource allocation strategies in Southeastern European health policy. Eur J Health Econ. 2013;14(2):153-9.

39. Pavlović N, Stanimirov B, Stojančević M, PautKusturica M, Stoimenova A, Goločorbin-Kon S, Mikov $M$. An insight on differences in availability and reimbursement of orphan medicines among Serbia, Bulgaria and Sweden. Biotechnology \& Biotechnological Equipment. 2012;26(5):3236-41.

40. Zlatareva A, Lakic D, Kamusheva M, Spaskov D, Momekov G, Petrova G. Analysis of Access to Orphan Drugs in Five Neighboring European Countries - Bulgaria, Greece, Macedonia, Romania and Ser- 
bia. World Journal of Pharmacy and Pharmaceutical Sciences. 2013;2(6):4415-34.

41. Regulations of the conditions, criteria, mode and procedure for placing a drug on the List of reimbursed drugs, amendments to the List of reimbursed drugs, or for removal of the drug from the List of reimbursed drugs. The Official Gazette of the Republic of Serbia, 41/2014, 125/2014 and 48/2015. [cited 2016Aug 07]. Available from:http://www. rfzo.rs/download/pravilnici/lekovi/Pravilnik_uslovi_ListaLekova-10062015.pdf.

42. Regulation of the List of the reimbursed drugs which are covered by compulsory health insurance. The Official Gazette of the Republic of Serbia, 65/2015, 71/2015, 104/2015, 24/2016, 57/2016, 61/2016 and 78/2016. [cited 2016Aug 07]. Available from: http://rfzo.rs/download/pravilnici/lekovi/ Pravilnik_o_listi_lekova27062016.pdf.

43. Law on Health Insurance. The Official Gazette of the Republic of Serbia, 107/2005, 109/2005, 30/2010, 57/2011, 110/2012, 119/2012, 99/2014, $123 / 2014,126 / 2014,106 / 2015$ and $10 / 2016$. [cited 2016Aug 07]. Available from: http://www. rfzo.rs/download/zakoni/Zakon_o_zdrav_osiguranju01042016.pdf.

44. Budget of the Ministry of Health of the Republic of Serbia for 2015. [cited 2016Aug 07]. Available from: http: //www.zdravlje.gov.rs/downloads/2015/Februar/Februar2015Budzet2015SluzbeniGlasnik.pdf.

45. Budget of the Ministry of Health of the Republic of Serbia for 2016. [cited 2016Aug 07]. Available from: http://www.zdravlje.gov.rs/ downloads/2016/April/April2016Budzet2016.pdf.

46. Jakovljevic MB, Djordjevic N, Jurisevic M, Jankovic S. Evolution of the Serbian pharmaceutical market alongside socioeconomic transition. Expert Rev Pharmacoecon Outcomes Res. 2015;15(3):52130.

47. Jakovljevic MB. Health expenditure dynamics in Serbia 1995-2012. Hospital Pharmacology - International Multidisciplinary Journal. 2014;1(3):180-3. (http://www.hophonline.org)

48. Jakovljevic M, Souliotis K. Pharmaceutical expenditure changes in Serbia and Greece during the global economic recession. South Eastern European Journal of Public Health. 2016;5(1).

49. Medicines and Medical Devices Agency of Serbia. Preparation of Professional Publications of the Agency. Report on turnover and consumption of pharmaceuticals in the Republic of Serbia in 2006. Belgrade, 2007. [cited 2016Jul 27]. Available from: http://www.alims.gov.rs/ciril/files/2012/09/02Promet-i-potrosnja-lekova-2006.pdf.

50. Medicines and Medical Devices Agency of Serbia. Preparation of Professional Publications of the Agency. Report on turnover and consumption of pharmaceuticals in the Republic of Serbia in 2007. Belgrade, 2008. [cited 2016Jul 27]. Available from: http: //www.alims.gov.rs/ciril/files/2012/09/03.
Promet-i-potrosnja-lekova-2007.pdf.

51. Medicines and Medical Devices Agency of Serbia. Preparation of Professional Publications of the Agency. Report on turnover and consumption of pharmaceuticals in the Republic of Serbia in 2008. Belgrade, 2009. [cited 2016Jul 27]. Available from: http: / /www.alims.gov.rs/ciril/files/2012/09/04Promet-i-potrosnja-lekova-2008.pdf.

52. Medicines and Medical Devices Agency of Serbia. Preparation of Professional Publications of the Agency. Report on turnover and consumption of pharmaceuticals in the Republic of Serbia in 2009. Belgrade, 2010. [cited 2016Jul 27]. Available from: http://www.alims.gov.rs/ciril/files/2012/09/05Promet-i-potrosnja-lekova-2009.pdf.

53. Medicines and Medical Devices Agency of Serbia. Preparation of Professional Publications of the Agency. Report on turnover and consumption of pharmaceuticals in the Republic of Serbia in 2010. Belgrade, 2011. [cited 2016Jul 27]. Available from: http: / /www.alims.gov.rs/ciril/files/2013/02/ Promet_2010.pdf.

54. Medicines and Medical Devices Agency of Serbia. Preparation of Professional Publications of the Agency. Report on turnover and consumption of pharmaceuticals in the Republic of Serbia in 2011. Belgrade, 2012. [cited 2016Jul 27]. Available from: http://www.alims.gov.rs/ciril/files/2012/06/092_ 13_02239_2013_5_001_1_pdf.pdf.

55. Medicines and Medical Devices Agency of Serbia. Preparation of Professional Publications of the Agency. Report on turnover and consumption of pharmaceuticals in the Republic of Serbia in 2012. Belgrade, 2013. [cited 2016Jul 27]. Available from: http://www.alims.gov.rs/ciril/files/2014/09/PROMET_javnost-2012.pdf.

56. Medicines and Medical Devices Agency of Serbia. Preparation of Professional Publications of the Agency. Report on turnover and consumption of pharmaceuticals in the Republic of Serbia in 2013. Belgrade, 2014. [cited 2016Jul 27]. Available from: http: / / www.alims.gov.rs/ciril/files/2016/03/ PPL_2013.pdf.

57. Lists of medicinal products for rare diseases in Europe. Orphanet Report Series. Orphan Drugs collection July 2016. [cited 2016Jul 27]. Available from: http://www.orpha.net/orphacom/cahiers/ docs/GB/list_of_orphan_drugs_in_europe.pdf.

58. European Medicines Agency [Internet]. Find medicine section. [cited 2016Jul 28]. Available from: http://www.ema.europa.eu/ema/index. jsp?curl=pages $/$ includes $/$ medicines $/$ medicines_ landing_page.jsp.

59. National Bank of Serbia [Internet]. Exchange Rate Lists For a Specific Period. [cited 2016Jul 29]. Available from: http://www.nbs.rs/export/sites/ default/internet/english/scripts/kl_period.html.

60. De Varax A, Letellier M, Börtlein G. Study of Orphan Drugs. Alcimed, 2004. [cited 2016Aug 02]. 
Available from: http://ec.europa.eu/health/files/ orphanmp/doc/pricestudy/final_final_report_ part_1_web_en.pdf.

61. Orofino J, Soto J, Casado MA, Oyagüez I. Global spending on orphan drugs in France, Germany, the UK, Italy and Spain during 2007. Appl Health Econ Health Policy. 2010;8(5):301-15.

62. Hutchings A, Schey C, Dutton R, Achana F, Antonov K. Estimating the budget impact of orphan drugs in Sweden and France 2013-2020. Orphanet J Rare Dis. 2014;9:22.

63. Medicines and Medical Devices Agency of Serbia [Internet]. Publications. [cited 2016Aug 06]. Available from: http://www.alims.gov.rs/ciril/o-agenciji/publikacije/.

64. Iskrov G, Miteva-Katrandzhieva T, Stefanov R. Challenges to orphan drugs access in Eastern Europe: the case of Bulgaria. Health Policy. 2012;108(1):10-8.

65. Krajnović D, Arsić J, Jocić D, Milošević Georgiev A, Tasić Lj, Marinković V.Evaluation of Pharmacists' Knowledge and Attitudes Regarding Rare Diseases and Orphan Drugs.Acta Medicae Medianae. 2013;52(2):23-32.

66. Jakovljevic MB. Oncology monoclonal antibodies expenditure trends and reimbursement projections in the emerging Balkan market. Farmeconomia. Health economics and therapeutic pathways. 2014;15(1):27-32.

67. Schey C, Milanova T, Hutchings A. Estimating the budget impact of orphan medicines in Europe: 2010 - 2020. Orphanet J Rare Dis. 2011;6:62. 


\title{
Trendovi prometa lekova "siročića" u Srbiji: analiza 8 godina tržišta lekova "siročića" u Srbiji
}

\author{
Ana V. Pejčić ${ }^{1}$, Georgi G. Iskrov²,3 \\ ${ }^{1}$ Fakultet medicinskih nauka, Univerzitet u Kragujevcu, Kragujevac, Srbija \\ ${ }^{2}$ Katedra za socijalnu medicinu i javno zdravlje, Fakultet za javno zdravlje, Medicinski Univerzitet u \\ Plovdivu, Plovdiv, Bugarska \\ ${ }^{3}$ Institut za retke bolesti, Plovdiv, Bugarska
}

\section{KRATAK SADRŽAJ}

Uvod/Cilj: Lekovi „siročići“ su medicinski proizvodi namenjeni za lečenje životno ugrožavajućih ili hronično onesposobljavajućih bolesti koje se javljaju kod malog broja bolesnika. Cilj ovog rada bio je da pruži uvid u trendove prometa lekova „siročića“ u Srbiji.

Materijal i metode: Kao izvor podataka o prometu lekova „siročića“ korišćene su publikacije,,Promet i potrošnja lekova za upotrebu u humanoj medicini u Republici Srbiji“ Agencije za lekove i medicinska sredstva Srbije (ALIMS) za period od 2006. do 2013. godine. $U$ analizu su uključeni lekovi koji su imali aktivan status lekova „siročića“ i aktivnu dozvolu za promet na tržištu Evropske Unije tokom posmatranog perioda. Za analizu podataka korišćene su metode deskriptivne statistike i opservacija hronoloških trendova.

Rezultati: U analiziranim publikacijama identifikovano je 12 lekova „siročića“. Promet lekova „siročića“ i udeo lekova „siročića“ u ukupnom prometu lekova za humanu upotrebu konstantno su se povećavali od 2006. do 2010. godine. Tokom 2011. i 2012. godine počeli su blago da opadaju, a zatim je u 2013. godini zabeleženo skoro trostruko smanjenje u odnosu na 2012. godinu. Udeo lekova „siročića“ u ukupnom prometu lekova za humanu upotrebu nije prešao $1 \%$ ukupnog prometa lekova za humanu upotrebu tokom posmatranog osmogodišnjeg perioda. Najveći udeo u prometu lekova „siročića“ imao je imatinib (87,36\%-97,13\%). Nagli pad u prometu lekova „siročića“ u 2013. godini mogao bi biti objašnjen činjenicom da je tokom 2012. godine imatinib povučen iz Registra lekova „siročića“ Evropske Unije.

Zaključak: Promet lekova „siročića“ od 2006. do 2013. godine bio je skoro neznatan u odnosu na ukupan promet lekova za humanu upotrebu. U poslednjoj posmatranoj godini primećen je značajan pad prometa, pre svega zbog činjenice da imatinib u toj godini nije više pripadao grupi lekova „siročića“. Da bi se istražili dugoročni trendovi potreban je veći vremenski horizont.

Ključne reči: lekovi „siročići“, farmaceutski troškovi, Srbija, retka bolest, potrošnja, promet 